\title{
EVALUATION OF BIOCHEMICAL INDICATORS IN BLOOD PLASMA OF RATS WITH TETRACYCLINE-INDUCED HEPATOSIS AND THEIR CORRECTION BY MILK PHOSPHOLIPIDS
}

\author{
V. A. GRYSHCHENKO ${ }^{1 凶}$, V. V. MUSIYCHUK ${ }^{1}$, V. O. CHERNYSHENKO', \\ O. V. GORNYTSKA', T. M. PLATONOVA ${ }^{2}$ \\ ${ }^{1}$ National University of Life and Environmental Sciences of Ukraine, Kyiv; \\ ${ }^{2}$ Palladin Institute of Biochemistry, National Academy of Sciences of Ukraine, Kyiv; \\ ৫e-mail:viktoriya_004@ukr.net
}

Received: 13 July 2018; Accepted: 13 December 2018

Tetracycline is a drug with direct cytotoxic action on the liver, and therefore it is widely used in pharmaceutical studies of therapeutic effectiveness of hepatoprotective preparations. The aim of the present work was to determine the biochemical indicators in blood plasma of rats with tetracycline-induced hepatosis and correction properties of milk phospholipids under tetracycline-induced hepatosis in rats. To achieve this, Wistar rats were administered $250 \mathrm{mg} / \mathrm{kg}$ of $4 \%$ tetracycline hydrochloride suspension once a day intragastrically. As the corrective therapy, 1\% solution of BAS "FLP-MD" was administered in liposomal form based on milk phospholipids. Under modeled steatohepatitis, significant destructive changes were observed in the cell membranes of hepatocytes in experimental rats. It was confirmed by higher activity of transaminase (in particular, activity of AST increased 4 times, that of ALT 1.7 times and the AST/ALT ratio was increased 2.4 times in blood plasma). The synthesis of clotting factors in livers of animals with hepatosis was inhibited. The content of fibrinogen in blood plasma decreased by 21\%, factor II (prothrombin) by 27.8\%, Xa-factor by $27.9 \%$, and protein C by $40.6 \%$. The animals also had hypochromic anemia, azotemia and bilirubinemia. The calcium-phosphor metabolism and hyperkalemia were observed. The liposomal BAS "FLP-MD" based on milk phospholipids diminished harmful effects of tetracycline, in particular supporting blood coagulation factors' level restoration, and also by the activity of transaminases. According to the results, it may be used in prophylactics and pharmaceutical correction of steatohepatitis.

Keywords: tetracycline-induced hepatosis, biochemical indicators, AST/ALT ratio, coagulation factors, milk phospholipids, hepatoprotection.

$\mathrm{D}$ espite the progress in the development and implementation into clinical practice of novel antimicrobial preparations that combine high activity with minimal side effects, treatment plans keep including traditional and easily available antibiotics such as penicillin, ampicillin, tetracycline and others $[1,2]$. Currently, up to $7-8 \%$ of the pharmaceutical market is occupied by tetracyclines and cephalosporines [3, 4]. The main side effects of the antibiotics under prolonged use in high doses are liver dysfunctions - from jaundice to hepatitis with further development of cirrhosis and fibrosis $[5,6]$. In some cases the hepatopathology goes into the decompensation stage, which requires long-term hepatoprotectors use.

Tetracycline is a drug with direct cytotoxic action upon the liver $[4,5]$. One of the first signs of liver toxicity is fat dystrophy of various degrees, or hepatosis - accumulation of lipids in hepatocytes. One of the causes of the pathology is imbalance of lipid synthesis and catabolism [7, 8]. Tetracycline use causes lower activity of mitochondrial $\beta$-oxidation of fatty acids, higher synthesis of endogenous fatty acids and insufficient incorporation or export of lipids to low-density lipoproteins [9].

(C) 2019 Gryshchenko V. A. et al. This is an open-access article distributed under the terms of the Creative Commons Attribution License, which permits unrestricted use, distribution, and reproduction in any medium, provided the original author and source are credited. 
An important part of toxic effect of tetracycline is inhibition of synthesis of mitochondrial oxidative phosphorylation enzymes, which are regulated at the transcription level; of enzyme complexes I and IV of the mitochondrial respiration electron transport chain, which in turn increases products of peroxide oxidation of lipids in liver and blood $[5,10,11]$. The compounds can disrupt structural organization of hepatocytic membranes and organelles, as seen from mitochondrial membrane depolarization with further swelling due to increased permeability for ions of the inner membrane, caused by free radicals [4].

This is in line with increased Calcium ions content in the microsomes of hepatocytes, which confirms membranotropic and prooxidant action of tetracycline and supports the centrality of mitochondrial dysfunction in the development of tetracycline induced hepatosis.

The liver plays the key role in the primary and secondary haemostasis since it is the site of synthesis of all clotting factors and their inhibitors [12, 13]. Hepatopathology leads to imbalance in the haemostasis system and to unstable balance between its pro- and anticoagulant components [14, 15]. Main hemostasis dysfunctions arising from liver pathology are the decrease in clotting factor synthesis and qualitative platelet changes (disruption of functional activity, lower platelet count, development of thrombocytopenia); decrease in fibrinolysis inhibitors [16].

Tetracycline liver injury in animals is widely used in pharmacological experiments to determine efficiency of hepatoprotective drugs [4, 17]. At tetracycline hepatosis, cell membranes are destroyed and their phospholipid organization disrupted, while collagen production is stimulated leading to fibrosis $[6,8]$. Therefore, last years saw interventions to restore structure and function of hepatocytes and to increase their "fluidity", to activate membrane enzymes, stabilize metabolism and lipid transport under fat hepatosis using essential phospholipids [18]. This became the basis for testing the efficiency of milk phospholipids whose fatty acid content is a good fit for the lipid content of cell membranes of mammalian internal organs.

The aim of present work was to determine the biochemical indicators in blood plasma of rats with tetracycline-induced hepatosis and correction properties of milk phospholipids under tetracyclineinduced hepatosis in rats.

\section{Materials and Methods}

Animal model. All manipulations with rats were performed according to the European Convention for the Protection of Vertebrate Animals (Strasbourg, 1986) and the Law of Ukraine "About protection of animals from cruelty" (Protocol N 3447 by 21.02.2006).60 Wistar male rats with body weight of 200-220 g were selected for the experiment based on the results of analogue principle [19]. Two weeks before the experiment rats were in separate cages with regular clinical examination. All animals received a balanced ration with all needed nutrients and active elements. They had free access to food and water. Body weight and food consumption were monitored constantly.

Three groups of animals 20 rats each were formed for the study. All experiments were performed according to modern principles of standardization of biomedical studies and principles of biological modeling [19].

Experimental acute fat hepatosis of rats was developed according to the previously developed method [20]. Rats of the $1^{\text {st }}$ and the $2^{\text {nd }}$ groups received intragastrically the suspension of tetracycline hydrochloride (Vitaminy, LTD, Ukraine) dissolved in $4 \%$ solution of starch daily in a dose $250 \mathrm{mg} / \mathrm{kg}$ of body weight, which was determined by daily weighting, during 7 days (overall volume 1.3-1.4 ml). This lead to constant toxic effect of tetracycline hydrochloride on liver tissue during the experiment. Animals of control group received daily the equivalent volume of physiological solution $(0.89 \%$ solution of Sodium chloride).

During the experiment animals of the 1st group did not receive any medications (self-rehabilitation). Animals of the $2^{\text {nd }}$ experimental group received intragastrically $1 \%$ liposome suspension of phospholipid-containing biologically active compound "FLPMD" in a dose $13.5 \mathrm{mg} / \mathrm{kg}$ of body weight (overall volume $0.27-0.30 \mathrm{ml}) 1$ hour before tetracycline administration and two days after the antibiotic was stopped.

Biologically active compound "FLP-MD" is our invention [21]. It contains a complex of different types of phospholipids of milk (butter milk) which has natural fatty acid composition natural for animal cell membrane including unsaturated fatty acids (oleic, linoleum, linolenic acid) and antioxidants (namely vitamins $\mathrm{E}$ and $\mathrm{A}$ ). 
The experiment lasted 9 days. On the $10^{\text {th }}$ day animals were sacrificed under ether anaesthesia.

Blood and blood plasma samples preparation. Samples of rat blood were collected by heart puncture. For hematology study 3.8\% sodium citrate was added to blood immediately after collection. For biochemical investigation the blood was stabilized with heparin. Platelet-rich plasma (PRP) was prepared from citrated blood by centrifugation at $1.000 \mathrm{rpm}$ for $30 \mathrm{~min}$. Platelet poor plasma (PPP) was obtained from PRP by centrifugation of PRP for $15 \mathrm{~min}$ at $1.500 \mathrm{rpm}$ [22]. Basic biochemical parameters were determined in heparin-stabilized blood and blood plasma, content of blood coagulation factors was determined in citrate-stabilized blood plasma.

Hemoglobin content was determined in whole blood using the Analyzer Micro CC-20 Plus Auto HTI (USA) according to the instructions of manufacturer.

Basic biochemical parameters were determined by biochemical GBG Stat Fax 1904 Plus (Awareness Technology, Inc., Florida, USA) using chemicals purchased from DAC-SPECTROMED S.R.L. (Moldova). This device allowed to determine routinely the content of total protein, albumin, conjugated and total bilirubin, creatinine, urea, glucose; activity of enzymes e.g. Aspartate transaminase (AST, EC 2.6.1.1), Alanine transaminase (ALT, EC 2.6.1.2), $\gamma$-glutamyl transpeptidase (GGT, EC 2.3.2.2), $\alpha$-amylase ( $\alpha$-AM, EC 3.2.1.1); and concentration of electrolytes (Potassium, Calcium, Phosphorus).

Fibrinogen concentration in blood plasma was determined by the modified spectrophotometric method using thrombin-like enzyme from the venom of Agkistrodon halys halys [23].

Total prothrombin level was estimated by the ecamulin-based test [13]. Thrombin generation induced by ecamulin was measured by chromogenic substrate assay using thrombin-specific S2238 (H-DPhe-Pip-Arg-pNA, Chromogenix, Sweden).

Protein $C$ level was determined using the activator of protein $C$ from Agkistrodon halys halys venom. The generation of activated protein $C$ was measured by chromogenic substrate assay using specific chromogenic substrate S2236 (p-Glu-Pro-ArgpNa, Chromogenix, Sweden) [24].

Factor X level was estimated using RVV - factor $\mathrm{X}$ activator from Russel vipera venom (Sigma, USA), and specific chromogenic substrate S2765 (ZD-Arg-Gly-Arg-pNA, Chromogenix, Sweden) according to recommendations of KABI Diagnostica.
Statistical data analysis was performed using Statistica 6.0. Data significance was estimated using Student's $t$-criteria. Results were assumed significant at $P<0.05$.

\section{Results and Discussion}

Basic biochemical indicators. Modelled tetracycline induced fat hepatosis is followed by functional and biochemical changes at the levels of the organism as a whole and liver in particular. Thus, the $1^{\text {st }}$ experimental group animals had slightly increased levels of total protein in blood plasma $10.4 \%$ compared to control, while albumin remained at the control levels (Table). It means that in rats' bodies it was the globulin-fraction proteins that underwent quantitative changes - the compounds whose functions include homeostatic, defensive, transport, regulatory, immune and many other ones [14]. Such changes indicate that in the bodies of rats with experimental fat hepatosis, there are intensively developing compensatory and adaptive processes to maintain homeostasis, due to the liver's active involvement in intermediary protein metabolism.

The 4.0- and 1.7-fold increase in the $1^{\text {st }}$ experimental group rats' plasma of AST and ALT, respectively (Table) indicates increasing intensity of intermediary metabolism of amino acids at the level of the liver, and also an increasing role of transamination processes and deamination in the development of fat hepatosis. It partially compensates the deficiency of energy substrates in hepatocytes that is typical for this pathology.

Meanwhile, the 2.4-fold increase in the AST/ ALT ratio in rats of the 1st experimental group (relative to control) points to mitochondrial cytopathy and associated structural and functional breakdown. That the blood of these animals had increased amounts of final products of nitrogen metabolism 2.0 -fold increase in urea, $18.1 \%$ in creatinine (Table) along with changes of activity of transaminases confirms the tendency towards increasing deamination in the tissues, and also suggests the development of secondary nephropathy. As a rule, this leads to general intoxication by the final products of nitrogen metabolism.

Meanwhile, the biochemical indicators in blood plasma of rats of the $2^{\text {nd }}$ experimental group indicate positive effect of the milk's phospholipids administered as liposomal biologically active compound "FLP-MD" on protein metabolism (Table). Total protein content and albumin content were within control 
Biochemical indicators of whole blood/plasma of rats with experimental hepatosis under tetracycline use and the corrective therapy with milk phospholipids ( $M \pm m, n=20$ in each group)

\begin{tabular}{|c|c|c|c|}
\hline Parameter & Control value & $\begin{array}{l}1^{\text {st }} \text { experimental group } \\
\text { (self-rehabilitation) }\end{array}$ & $\begin{array}{l}2^{\text {nd }} \text { experimental group } \\
\text { (therapy with "FLP-MD") }\end{array}$ \\
\hline Total protein $\mathrm{g} / \mathrm{l}$ & $66.7 \pm 2.1$ & $73.6 \pm 2.2^{*}$ & $71.90 \pm 3.01$ \\
\hline Albumin, $g / 1$ & $37.5 \pm 1.5$ & $34.2 \pm 1.3$ & $40.5 \pm 1.6$ \\
\hline $\begin{array}{l}\text { Alanine } \\
\text { transaminase, IU }\end{array}$ & $97.6 \pm 6.9$ & $162.3 \pm 10.3^{*}$ & $137.3 \pm 7.1^{*}$ \\
\hline $\begin{array}{l}\text { Aspartate } \\
\text { transaminase, IU }\end{array}$ & $90.3 \pm 3.6$ & $361.9 \pm 14.8^{*}$ & $178.2 \pm 8.2^{*}$ \\
\hline AST/ALT ratio & $0.93 \pm 0.01$ & $2.23 \pm 0.08^{*}$ & $1.30 \pm 0.02 *$ \\
\hline Creatinine, $\mu \mathrm{M}$ & $40.40 \pm 2.11$ & $47.71 \pm 2.23^{*}$ & $42.30 \pm 2.04$ \\
\hline Urea, мM & $6.9 \pm 0.3$ & $13.9 \pm 0.4^{*}$ & $6.8 \pm 0.2$ \\
\hline Hemoglobin, g/1 & $184.5 \pm 12.4$ & $156.0 \pm 6.1^{*}$ & $310.5 \pm 20.2^{*}$ \\
\hline Total bilirubin, $\mu \mathrm{M}$ & $3.1 \pm 0.2$ & $54.4 \pm 2.1^{*}$ & 7. $3 \pm 0.6^{*}$ \\
\hline $\begin{array}{l}\text { Conjugated } \\
\text { bilirubin, } \mu \mathrm{M}\end{array}$ & $1.43 \pm 0.24$ & $27.22 \pm 0.84^{*}$ & $3.02 \pm 0.23^{*}$ \\
\hline Glucose, mM & $6.40 \pm 0.13$ & $6.60 \pm 0.07$ & $7.10 \pm 0.09^{*}$ \\
\hline $\begin{array}{l}\gamma \text {-glutamyl } \\
\text { transpeptidase, IU }\end{array}$ & $6.9 \pm 0.4$ & $7.1 \pm 0.2$ & $7.0 \pm 0.4$ \\
\hline$\alpha$-amylase, IU & $609.6 \pm 22.4$ & $649.7 \pm 18.2$ & $446.5 \pm 16.3^{*}$ \\
\hline $\mathrm{K}^{+}, \mathrm{mM}$ & $3.54 \pm 0.18$ & $6.30 \pm 0.21^{*}$ & $3.70 \pm 0.16$ \\
\hline $\mathrm{Ca}^{2+}, \mathrm{mM}$ & $2.03 \pm 0.10$ & $4.37 \pm 0.23^{*}$ & $2.58 \pm 0.06^{*}$ \\
\hline Pinorganic, $\mathrm{mM}$ & $3.35 \pm 0.24$ & $4.05 \pm 0.12^{*}$ & $1.85 \pm 0.10^{*}$ \\
\hline
\end{tabular}

*Results were significant for $P \leq 0.05$ when compared to control.

ranges (Table). There was a tendency to decreased activity of AST and ALT, although the parameters were still high compared to control: they were increased 1.7- and 1.4-fold, respectively. The AST/ALT ratio was also lower, but remained 1.4 times higher than the control one.

Despite the increased activity of AST, ALT and their ratio, the data suggest gradual normalization of transaminase activity in sick rats' plasma under administration of the biologically active compound "FLP-MD" in liposomal form. Besides that, blood of these rats was found to contain normalized urea and creatinine levels (Table).

The development of experimental hepatosis affects hemoglobin metabolism which underwent significant change in the $1^{\text {st }}$ group of animals. As a result, there developed hypochromia (hemoglobin level decreased by $15.4 \%$ compared to control) and anemia (Table). The latter one can be a consequence of lower hematopoietic activity of the bone marrow, increased hemolytic processes due to negative impact of toxins on the structural organization of membranous systems of the erythrocytes in the bloodstream and induction of pathologic processes in liver parenchyma that is an additional organ of hemopoiesis. Thus, the animals' plasma showed development of hyperbilirubinemia (total bilirubin grew 17.6 times compared to control), while the levels of its conjugated and unconjugated forms both increased, indicating disrupted pigment function of the liver.

In rats of the $2^{\text {nd }}$ experimental groups, under administration of biologically active compound "FLP-MD" in liposomal form, hemoglobin level in blood even exceeded the control 1.7 times, perhaps due to compensatory mobilization of erythrocytes from their reserves. The bile pigment metabolism indicators also were increased, but they were near the control values (Table).

We showed glucose content increase in plasma of the $2^{\text {nd }}$ experimental group of rats by $11 \%$ com- 
pared to control, indicating glucose mobilization by the organism to maintain energy balance and fasten regeneration of the tissues.

Meanwhile, the lack of significant changes in the blood of the $1^{\text {st }}$ group of rats in the activity of $\gamma$-glutamyl-trans-peptidase and $\alpha$-AM precludes development of cholestasis and pancreatic complications (Table). Lower activity of $\alpha$-AM (by $26.8 \%$ ) in the plasma of rats of the $2^{\text {nd }}$ experimental group compared to control might indicate metabolic changes in the pancreas, which in turn cause the abovementioned changes in glucose levels.

In rats of the $1^{\text {st }}$ experimental group with acute hepatosis, it was typical that the level of intracellular macroelements in blood plasma increased: Potassium - 1.8 times, Calcium -2.2 times, Phosphorus 1.2 times, which have might negatively reflected on the cellular metabolism (Table). Meanwhile, mobilization of Calcium and Phosphorus from their main storage reservoir, the bone tissue, might lead to secondary osteopathy, which obviously would enhance the negative consequences of anemia diagnosed in the animals of the $1^{\text {st }}$ experimental group during selfrehabilitation. Yet the deviation in Calcium $(27 \%$ increase) and Phosphorus ( $45 \%$ decrease) in the plasma of the rats of the $2^{\text {nd }}$ experimental group indicates gradual restoration of the bone tissue structure, even under the corrective therapy.

Hemostasis system parameters. The liver is the main supporter and stabilizer of the hemostasis system that provides almost all of its coagulant and anticoagulant protein factors, as well as eliminates metabolites produced by coagulation processes. The content/activity of blood clotting system factors depend on the liver's condition, and these parameters exactly characterize its protein-synthesizing function.

Since the liver is the place of synthesis of key pro-coagulant components - fibrinogen, factor II (prothrombin), clotting factor $\mathrm{X}$, and the main anticoagulant factor - protein $\mathrm{C}$, these parameters were selected for studying in our research.

Fibrinogen is a protein of the acute phase of inflammation, and its content either stays within the norm or increases during liver pathology. Low fibrinogen content (lesser than $1 \mathrm{~g} / \mathrm{l}$ ) is found only at very serious pathologies if its synthesis is disrupted [14]. The content of fibrinogen in blood plasma of rats of the $1^{\text {st }}$ experimental group under tetracycline induced hepatosis was $21 \%$ lower compared to control. In the blood plasma of animals with induced hepatosis under administration of biologically active compound "FLP-MD", fibrinogen content was within normal ranges (Fig.).

Thus, a decrease of fibrinogen level in blood plasma of rats of the $1^{\text {st }}$ experimental group indicated a disruption of protein-synthesizing function of the liver after tetracycline administration. Normalization of the parameter in the plasma of rats of the $2^{\text {nd }}$ group indicates hepatoprotective effect of "FLP-MD".

Normally evaluation of the hemostasis system at liver pathology includes standard coagulation diagnostic tests. However, diagnostics by coagulation laboratory tests is complicated, since the clotting time of plasma depends not only on the total rate of coagulation factors, but also on the presence of clotting inhibitors and on fibrinogen content [25].

That is why we developed model systems in which the activation of coagulation factors - prothrombin, factor $\mathrm{X}$ and protein $\mathrm{C}$ - was measured spectrophotometrically by cleaving of specific chromogenic substrates. This approach, unlike coagulation tests, lets us exclude the effect of fibrin polymerization inhibitors since enzyme produced during activation causes cleavage of the chromogenic substrate but not the fibrinogen to fibrin transformation with following polymerization (as in the coagulation tests).

Determination of prothrombin content allows evaluating the rate of coagulopathy and level of liver dysfuncion, in particular the changes in protein synthesis. The research established the tendency (compared to control) towards lower prothrombin levels in both the $1^{\text {st }}$ group of rats (by $27.8 \%$, under tetracycline-induced hepatosis) and in the $2^{\text {nd }}$ group (by $18.2 \%$, corrective therapy using "FLP-MD". The corrective effect of the "FLP-MD" is notable: the level of prothrombin in blood plasma of the rats of the $2^{\text {nd }}$ group was lower than control but probably higher than in the $1^{\text {st }}$ group (by $9.6 \%$ ).

A similar trend was seen in factor X content: in the $1^{\text {st }}$ group, it was $27.9 \%$ lower than control, while in the the $2^{\text {nd }}$ group, it was restored (Fig., $C$ ). Therefore, the data indicate a disrupted protein-synthesizing function of the liver and confirm the hepatoprotective effect of the "FLP-MD".

Protein $\mathrm{C}$ is a vitamin K-dependent glycoprotein produced mostly by hepatocytes. In acute and chronic liver diseases its content decreases together with other clotting factors, characterizing the degree to which the liver's protein-synthesizing function is 
$\boldsymbol{A}$

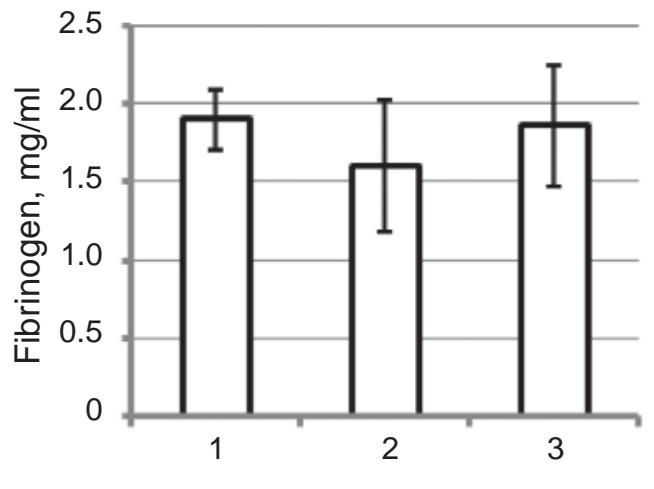

C

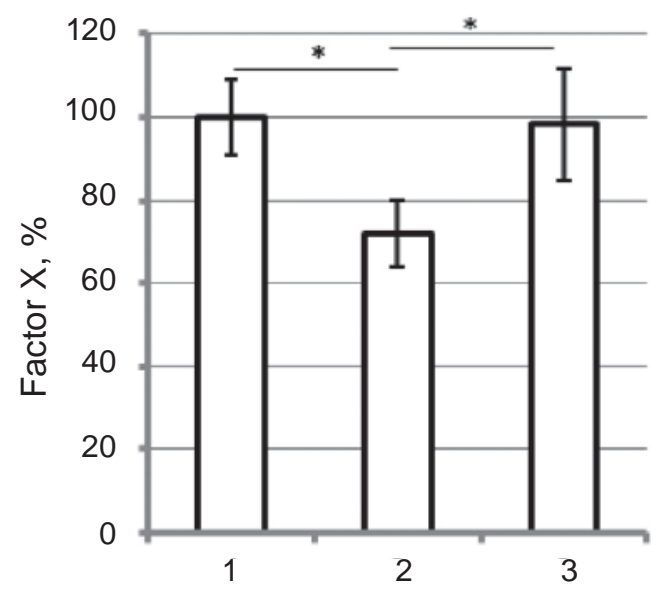

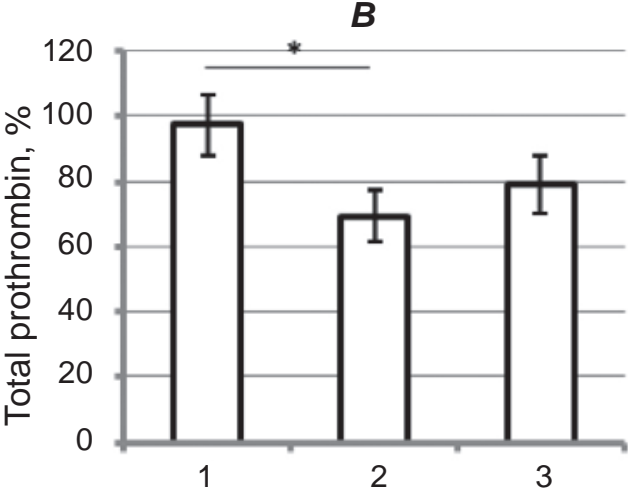

D

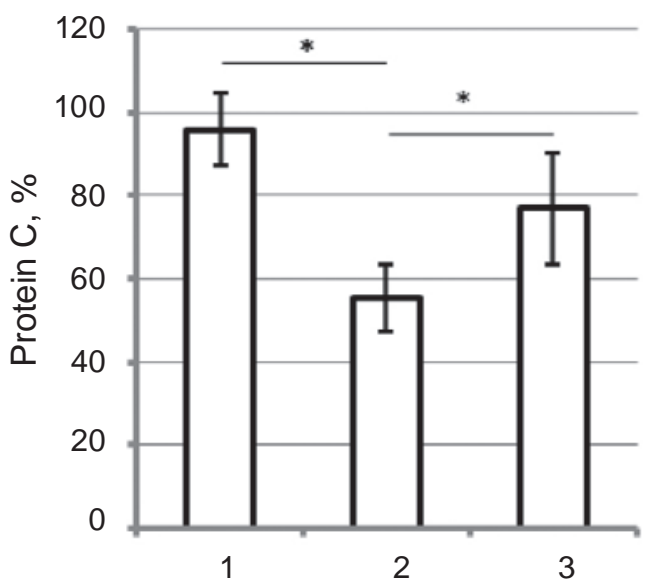

Fig. 1. Fibrinogen concentration (A), total prothrombin level (B), level of factor $X(C)$ and protein $C(\mathbf{D})$ in blood plasma of rats with tetracycline-induced hepatosis and their correction by biologically active compound "FLP-MD". 1 - Control group of rats, $n=20 ; 2$ - rats with experimentally induced hepatosis during self-rehabilitation, $n=20 ; 3$ - rats with experimentally induced hepatosis during administration of biologically active compound "FLP-MD", $n=20$. *Results were significant for $P \leq 0.05$

disrupted [14]. Rats in both experimental groups had lower than control protein $C$ levels in the blood: in the 1st experimental group, with tetracycline-induced hepatosis it was reduced by $40.6 \%$, and in the $2^{\text {nd }}$ group with corrective therapy - by $19.0 \%$. The corrective effect of "FLP-MD" is supported by the 21.6\% increase in protein $C$ content in the plasma of the $2^{\text {nd }}$ group compared to the $1^{\text {st }}$ one (Table).

Therefore, changing levels of fibrinogen, clotting factors II and $\mathrm{X}$, and protein $\mathrm{C}$ are both the indicators of protein-synthesizing dysfunction of the liver and of the efficiency of corrective therapy by the hepatoprotector in the liposomal form of "FLP-MD". Thus, we can recommend determination of vitamin K-dependent proteins for diagnostics of hepatosis. Such approach allowed us to find a valuable hepatoprotective effect of "FLP-MD" which leads to recovery of protein-synthesizing function of liver even at acute hepatosis.
Conclusions. Modeling tetracycline-induced hepatosis an increased activity of transaminases and their ratio, inhibition of protein-synthesizing function of the liver (a decrease in clotting factors content). Meanwhile, blood plasma contained increased amounts of creatinine, urea, and total bilirubin.

Using phospholipids of milk as $1 \%$ solution of the liposomal biologically active compound "FLP-MD" with strong membranotropic and reparative action on the damaged liver cells stimulates the recovery of metabolic disruptions, mostly proteins. Using this bioadditive could prevent possible complications - anemia, coagulo-, nephro- and osteopathy, parenchymatous jaundice and intoxication. The obtained results suggest that the liposomal biologically active compound "FLP-MD" based on milk phospholipids is a promising agent for prophylactics and pharmacological correction of drug-induced hepatosis. 
Conflict of interest. Authors have completed the Unified Conflicts of Interest form at http:// ukrbiochemjournal.org/wp-content/uploads/2018/12/ coi_disclosure.pdf and declare no conflict of interest.

\section{ОЦІНКА БІОХІМІЧНИХ ПОКАЗНИКІВ ПЛАЗМИ КРОВІ ЩУРІВ ЗА ТЕТРАЦИКЛІН- ІНДУКОВАНОГО ГЕПАТОЗУ ТА ЇХ КОРИГУВАННЯ ФОСФОЛІПІДАМИ МОЛОКА}

\section{B. А. Грищенко ${ }^{1 \bowtie}$, В. В. Мусійчук 1 , В. О. Чернишенко ${ }^{2}$, О. В. Горницька ${ }^{2}$, T. М. Платонова ${ }^{2}$}

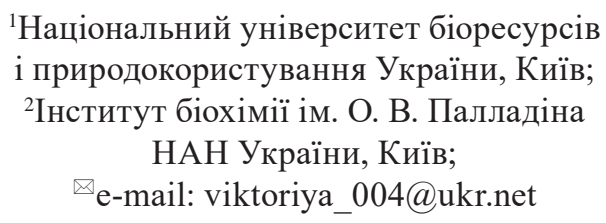

Тетрациклін виявляє виражений цитотоксичний ефект на печінку, відтак його широко використовують для тестування терапевтичної ефективності гепатопротекторних препаратів. Метою роботи було визначення біохімічних показників плазми крові щурів та коригувальних властивостей фосфоліпідів молока за тетрациклініндукованого гепатозу. Для моделювання гепатозу щурам щоденно вводили 4\%-й розчин тетрацикліну гідрохлориду в дозі 250 мг/кг маси тіла внутрішньошлунково. Корекційну терапію проводили за допомогою 1\%-ї суспензії фосфоліпідів молока у формі ліпосомальної біологічно активної добавки «FLP-MD». Експериментальний гепатоз зумовлював вірогідні деструктивні зміни в мембранах гепатоцитів. Це було підтверджено підвищеною амінотрансферазною активністю (зокрема, в плазмі крові активність АСТ зростала у 4,0 раза, АЛТ - в 1,7 раза та їх співвідношення - у 2,4 раза). У щурів із гепатозом відмічено зниження синтезу факторів зсідання крові. Зокрема, вміст фібриногену в плазмі крові на тлі гепатозу знижувався на 21\%, протромбіну - на 27,8\%, фактоpa Ха - на $27,9 \%$, протеїну С - на $40,6 \%$. У цих тварин відзначали гіпохромемію як прояв анемії за розвитку гіперазотемії та гіпербілірубінемії. Виявлено порушення фосфорно-кальцієвого обміну та гіперкаліємію. Показано, що вве- дення хворим тваринам фосфоліпідів молока у формі ліпосомальної біологічно активної добавки «FLP-MD» зменшувало прояв негативних ефектів тетрацикліну, про що свідчить відновлення рівня коагуляційних факторів та амінотрансферазної активності. Результати біохімічних досліджень дозволяють рекомендувати «FLP-MD» як засіб гепатопротекції.

К л ю ч о в і с лов в: тетрациклініндукований гепатоз, біохімічні показники, співвідношення АСТ/АЛТ, фактори зсідання крові, фосфоліпіди молока, гепатопротекція.

\section{References}

1. Okudo J, Anusim N. Hepatotoxicity due to clindamycin in combination with acetaminophen in a 62-year-old african american female: a case report and review of the literature. Case Reports Hepatol. 2016; 2016: 2724738.

2. Bawany MZ, Bhutto B, Youssef WI, Nawras A, Sodeman T. Acute liver failure: an uncommon complication of commonly used medication. Am J Ther. 2013; 20(5): 566-568.

3. Begriche K, Massart J, Robin MA, BorgneSanchez A, Fromenty B. Drug-induced toxicity on mitochondria and lipid metabolism: mechanistic diversity and deleterious consequences for the liver. J Hepatol. 2011; 54(4): 773-794.

4. Teschke R, Schulze J, Schwarzenboeck A, Eickhoff A, Frenzel C. Herbal hepatotoxicity: suspected cases assessed for alternative causes. Eur J Gastroenterol Hepatol. 2013; 25(9): 10931098.

5. Björnsson ES, Hoofnagle JH. Categorization of drugs implicated in causing liver injury: Critical assessment based on published case reports. Hepatology. 2016; 63(2): 590-603.

6. Fabbrini E, Magkos F. Hepatic steatosis as a marker of metabolic dysfunction. Nutrients. 2015; 7(6): 4995-5019.

7. Kawano Y, Cohen DE. Mechanisms of hepatic triglyceride accumulation in non-alcoholic fatty liver disease. J Gastroenterol. 2013; 48(4): 434441.

8. Bechmann LP, Hannivoort RA, Gerken G, Hotamisligil GS, Trauner M, Canbay A. The interaction of hepatic lipid and glucose metabolism in liver diseases. J Hepatol. 2012; 56(4): 952-964. 
9. Blas-García A, Apostolova N, Valls-Bellés V, Esplugues JV. Endoplasmic Reticulum and Mitochondria: Independent Roles and Crosstalk in Fatty Liver Diseases and Hepatic Inflammation. Curr Pharm Des. 2016; 22(18): 2607-2618.

10. Devbhuti P, Saha A, Sengupta C. Clindamycin: effects on plasma lipid profile and peroxidation parameters in rabbit blood plasma. Acta Pol Pharm. 2015; 72(2): 253-260.

11. Rui L. Energy metabolism in the liver. Compr Physiol. 2014; 4(1): 177-197.

12. Rousseau A, Woodhams B, Paunet-Bobo M, Van Dreden P, Bigot D, Leclerc S, Lenormand B, Vasse M. Decreased procoagulant phospholipids in patients treated by vitamin $\mathrm{K}$ antagonists. Thromb Res. 2012; 130(3): 491-494.

13. Hryshchenko VA, Tomchuk VA, Lytvynenko OM, Chernyshenko VO, Gryshchuk VI, Platonova TM. An estimate of protein synthesis in liver under induced hepatitis. Ukr Biokhim Zhurn. 2011; 83(1): 63-68. (In Ukrainian).

14. Kopec AK, Joshi N, Luyendyk JP. Role of hemostatic factors in hepatic injury and disease: animal models de-liver. J Thromb Haemost. 2016; 14(7): 1337-1349.

15. Versteeg HH, Heemskerk JW, Levi M, Reitsma PH. New fundamentals in hemostasis. Physiol Rev. 2013; 93(1): 327-358.

16. Owens AP 3rd, Mackman N. Microparticles in hemostasis and thrombosis. Circ Res. 2011; 108(10): 1284-1297.

17. Yu HY, Wang BL, Zhao J, Yao XM, Gu Y, Li Y. Protective effect of bicyclol on tetracyclineinduced fatty liver in mice. Toxicology. 2009; 261(3): 112-118.

18. Grattagliano I, Diogo CV, Mastrodonato M, de Bari O, Persichella M, Wang DQ, Liquori A,
Ferri D, Carratù MR, Oliveira PJ, Portincasa P. A silybin-phospholipids complex counteracts rat fatty liver degeneration and mitochondrial oxidative changes. World J Gastroenterol. 2013; 19(20): 3007-3017.

19. Vlizlo VV, Fedoruk RS, Ratych IB. Laboratory methods of investigation in biology, stockbreeding and veterinary. Spolom, Lviv, 2012. 764 p. (In Ukrainian).

20. Melnychuk DO, Tomchuk VA, Yanchuk PI, Gryshchenko VA, Reshetnyk EM, Synelnyk TB. Research methods of liver and biliar system functional state. Kyiv: NUBiP Ukraine, 2015. 414 p. (In Ukrainian).

21. Pat. 86516 UA, ICP $61 \mathrm{~K} 35 / 20$, A23K 1/00. Veterinary bioactive addidition of liposomal form and method of reparative therapy in hepatology / Melnychuk D. O., Gryshchenko V. A., Lytvynenko O. M. Publ. 27.04.2009, Bul. N 8. (In Ukrainian).

22. Dolgov VV, Svirin PV. Laboratory diagnostics of hemostasis disorders. M.-Tver': Triada, 2005. 227 p. (In Russian).

23. Sokolovska AS, Chernyshenko TM, Ivanenko TI. Comparative characteristic of methods for determination of the fibrinogen content in blood plasma. Exp Clin Physiol Biochem. 2002; 3: 8286. (In Ukrainian).

24. Gornitskaya OV, Platonova TN. Purification and characteristic of the protein $\mathrm{C}$ activator from Agkistrodon halys halys snake venom. Biomed Khimia. 2003; 49(5): 470-479 (In Russian).

25. Forkin KT, Colquhoun DA, Nemergut EC, Huffmyer JL. The coagulation profile of endstage liver disease and considerations for intraoperative management. Anesth Analg. 2018; 126(1): 46-61. 